\title{
Can a scientist believe in the resurrection? Three hypotheses.
}

\author{
Ian $\mathrm{H}$. Hutchinson \\ https://doi.org/10.54739/iy72
}

1

$\mathrm{m}$ a professor of nuclear science and engineering at MIT, and today, I am celebrating the resurrection of Jesus. So are dozens of my colleagues. How can this be?

Hypothesis one: We're not talking about a literal resurrection. Perhaps it is just an inspiring myth that served to justify the propagation of Jesus' exalted ethical teachings. A literal resurrection contradicts the known laws of nature. Maybe scientists can celebrate the idea of Jesus's spirit living on, while his body remained in the grave.

But the first disciples attested to a physical resurrection. How could an untruth logically support high moral character? How could it have sustained the apostles through the extremes of persecution they experienced founding Christianity? And is celebrating a myth consistent with scientific integrity?

Hypothesis two: We really believe in the bodily resurrection of the first century Jew known as Jesus of Nazareth. My Christian colleagues at MIT - and millions of other scientists worldwide somehow think that a literal miracle like the resurrection of Jesus is possible. And we are following a long tradition. The founders of the scientific revolution and many of the greatest scientists of the intervening centuries were serious Christian believers. For Robert Boyle (of the ideal gas law, co-founder in 1660 of the Royal Society) the resurrection was a fact. For James Clerk Maxwell (whose Maxwell equations of 1862 govern electromagnetism) a deep philosophical analysis undergirded his belief in the resurrection. And for William Phillips (Nobel prize-winner in 1997 for methods to trap atoms with laser light) the resurrection is not discredited by science.

To explain how a scientist can be a Christian is actually quite simple. Science cannot and does not disprove the resurrection. Natural science describes the normal reproducible working of the world of nature. Indeed, the key meaning of "nature", as Boyle emphasized, is "the normal course of events." Miracles like the resurrection are inherently abnormal. It does not take modern science to tell us that humans don't rise from the dead. People knew that perfectly well in the first century; just as they knew that the blind from birth don't as adults regain their sight, or water doesn't instantly turn into wine.

This article was first published Easter of 2016, on the website of the Veritas Forums. Subsequently it was deleted in a website redesign. Published here with permission of the author.

Maybe science has made the world seem more comprehensible although in some respects it seems more wonderful and mysterious. Maybe superstition was more widespread in the first century than it is today - although the dreams of today's sports fans and the widespread interest in the astrology pages sometimes make me wonder. Maybe people were more open then to the possibility of miracles than we are today. Still, the fact that the resurrection was impossible in the normal course of events was as obvious in the first century as it is for us. Indeed that is why it was seen as a great demonstration of God's power.

To be sure, while science can't logically rule miracles in or out of consideration, it can be a helpful tool for investigating contemporary miraculous claims. It may be able to reveal self-deception, trickery, or misperception. If someone has been seen levitating on a supposed flying carpet in their living room, then the discovery of powerful electromagnets in their basement might well render such claims implausible. But if science fails to find defeating evidence then it is unable to say one way or the other whether some reported inexplicable event happened, or to prove that it is miraculous. Science functions by reproducible experiments and observations. Miracles are, by definition, abnormal and non-reproducible, so they cannot be proved by science's methods.

Today's widespread materialist view that events contrary to the laws of science just can't happen is a metaphysical doctrine, not a scientific fact. What's more, the doctrine that the laws of nature are "inviolable" is not necessary for science to function. Science offers natural explanations of natural events. It has no power or need to assert that only natural events happen.

So if science is not able to adjudicate whether Jesus' resurrection happened or

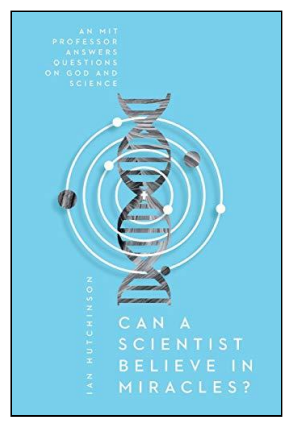
not, are we completely unable to assess the plausibility of the claim? No. Contrary to increasingly popular opinion, science is not our only means for accessing truth. In the case of Jesus' resurrection, we must consider the historical evidence, and the historical evidence for the resurrection is as good as for almost any event of ancient history. The extraordinary character of the event, and its significance, provide a unique context, and ancient history is necessarily hard to establish. But a bare presumption that science has shown the resurrection to be impossible is an intellectual copout. Science shows no such thing. 
Hypothesis three: I was brainwashed as a child. If you've read this far and you are still wondering how an MIT professor could seriously believe in the resurrection, you might guess I was brainwashed to

believe it as a child. But no, I did not grow up in a home where I was taught to believe in the resurrection. I came to faith in Jesus when I was an undergraduate at Cambridge University and was baptized in the chapel of Kings College on my 20th birthday. The life, death and resurrection of Jesus Christ are as compelling to me now as then.

\section{References}

Ian Hutchinson, Can a scientist believe in miracles?, 2018. 